\title{
RADEC Learning Model (Read-Answer-Discuss-Explain And Create): The Importance of Building Critical Thinking Skills In Indonesian Context
}

\author{
Yoga Adi Pratama $a^{1, a^{*}}$, Wahyu Sopandi1,b, and Yayuk Hidayah ${ }^{2, c}$ \\ ${ }^{1}$ Primary School Education Study Program, Universitas Pendidikan Indonesia, Bandung, Indonesia \\ 2Primary School Teacher Education Study Program, Ahmad Dahlan University, Yogyakarta, Indonesia \\ a yoga.a@student.upi.edu; c yayuk.hidayah@pgsd.uad.ac.id \\ ${ }^{*}$ Corresponding Author \\ Whatsapp Number: [+62-81278897089]
}

How to Cite : Pratma, Y., A., Sopandi., W \& Hidayah, Y., (2019). RADEC Learning Model (Read-Answer-Discuss-Explain And Create): The Importance of Building Critical Thinking Skills In Indonesian Context. International Journal for Educational and Vocational Studies, 1 (2), 109-115.

\section{ARTICLE HISTORY}

Received:3 May 2019

Revised: 23 May2019

Accepted: 29 May 2019

\section{KEYWORDS}

RADEC Learning;

Learning Model;

Critical Thinking;

\section{ABSTRACT}

The purpose of writing this article was to describe RADEC learning model in building critical thinking skills. This study was conducted because of the need for a learning model that fits the Indonesian context to build critical thinking skills that can be used at elementary school level. This study used the literature review. This study produced one solution to be able to build critical thinking skills using RADEC learning model (read-answer-discuss-explain and create). The approach in learning done by the teacher plays a role in improving critical thinking skills. The teacher needs to use a learning model that can stimulate students' critical thinking skills.

This is an open access article under the CC-BY-SA license.

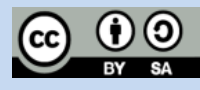

\section{INTRODUCTION}

The $21^{\text {st }}$ century is a digital century signed by the rapid development of information and communication technology. The development of information technology provides changes in all aspects of the life constellation . The implication is that every nation including Indonesia must adjust to the demands of the era. According to Binkley et al. (2012, pp. 18-19) to be able to live in the $21^{\text {st }}$ century, ten skills that students must possess, these skills include creative thinking skills, critical thinking, metacognition thinking, communication, collaboration, information literacy,ICT literacy (Information Technology Communication), having citizenship, work and career, as well as individual and social responsibility skills. Furthermore, Trilling \& Fadel (2009, p. 47) initiated the concept of a rainbow of skills and knowledge that must be possessed in the 21st century. These skills include learning and innovation skills in which there are creative thinking and problem solving skills, communication and collaboration skills, and ability to creativity and innovate. These skills are an essential basis for someone to be able to exist in the $21^{\text {st }}$ century.
By using holistic approach, the Center for Curriculu designs the curriculum by offering four dimensions of education: knowledge, skills, character, and metacognition as follows:

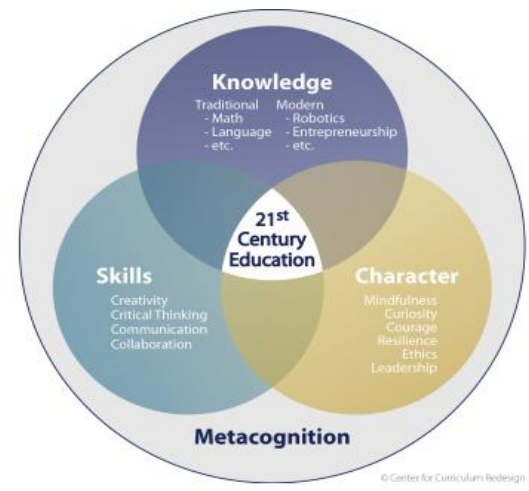

To learn more about the work and focus of the Center for Curriculum Redesign, please visit our website at www.curriculumredesign.org/about/background

Therefore one of the important skills in the 21st century is critical thinking skills. The ability to think critically needs to be developed and familiarized by each 
individual (F. Fakhriyah, 2014). The critical thinking component includes meganalysis skills, deducing deductive thinking, evaluating and solving problems (Emily R. Lai, 2011). Meanwhile, The National Council for Excellence defines critical thinking is the conceptualization application of analyzing, synthesizing, evaluating information obtained through experience, application and reflection (Maya Bialik, Charles Fadel, 2015).

Critical thinking skills need to be possessed by each individual to achieve balance in the $21^{\text {st }}$ century, especially for elementary school teachers. this is because $21^{\text {st }}$ century teachers need to master the content of teaching skills and integrating teaching with technology (Hafsah Jan, 2017), In the $21^{\text {st }}$ century between national and international will intersect with each other (Helen B. Boholano, 2017). However, in learning practices teachers tend to be less concerned about improving critical thinking skills. This lack of awareness is reflected in the results of the PISA and TIMSS studies. Althought it increases, which was ranked $64^{\text {th }}$ out of 65 countries in 2012 (OECD, 2013) and ranked $64^{\text {th }}$ out of 72 countries in 2015 (OECD, 2017), Indonesia is still at a low level. Indonesia is still at the low ability level when viewed from cognitive aspects (knowing, applying, reasoning) (Kusuma, et al., 2017). In line with PISA, the results of the TIMSS study of Indonesian students in 2011 was on $40^{\text {th }}$ rank out of 42 countries and in 2015 was on $45^{\text {th }}$ rank out of 48 countries (TIMSS, in Nugroho, 2018). The results of these studies adequately prove that Indonesian students are weak in critical thinking skills.

The main cause of low critical thinking skills is learning still adopts traditional system that is teacher-centered. The dominance of the teacher during learning is too high, it makes students only the object of learning. Based on research conducted by Saido et al. (2015) it can be concluded that teachers tend to teach students to memorize, while innovative learning that is investigative is still not implemented by the teacher. These results are in line with Sopandi's research et al. (2019) which states that teachers do not understand the syntax of innovative learning models, so the impact of conventional learning models remains a mainstay of teachers. Activity in the classroom is dominated by an assignment and memorization, it causes low participation of students' thinking skills in learning (Tembang, 2017). There are still many memorizing materials contained in the short term memory, so that the thinking ability of students in Indonesia is only at the level of remembering, restating, or referring without processing (recite) (Nugroho, 2018, p. 12).

The lack of innovative learning model practice is very poorly used by teachers in learning. The results of Sopandi's research, et al. (2019) showed that only $10 \%$ of primary and secondary education teachers in West Java could write the syntax of the innovative learning model that is often used, the other teachers did not understand and could not rewrite the syntax or the teacher felt that they had implemented an innovative learning model but in fact they did not do that. This fact provides evidence that the teacher only feels implementing an innovative learning model. So that we can know that innovative learning models are still not maximally applied in Indonesia.

On the other hand, one of the competence in the 2013 curriculum is to develop creativity, curiosity, the ability to form questions and to form critical thoughts that need to live smart and lifelong learning (Permendikbud, 2013) Therefore, it is proper to use learning models to improve critical thinking applied in the teaching and learning process by teacher. There is a teacher's strategic position in improving students' thinking skills, the approach used by teachers to foster critical thinking in students (Ni Putu Ayu Nopta Apsari, 2016).

Previous research on the use of learning models in fostering critical thinking was carried out by Alifa Noora Rahma (2012), Development of Learning Tool Model using Inquiry Approaches of Solubility Material Sets and Solubility Results to Grow Critical Thinking Skills and Student Empathy Against the Environment to produce, chemical learning process with models inquiry with SETS approach to foster critical thinking skills is marked by an increase in the average score of the pre test and post test in each critical thinking indicator, which was 29.45 to 77.08. The average score of indicators of critical thinking skills in practical discussion activities was 81.10. The increase in the value of the pre-post $\mathrm{N}$-gain test was 0.72 with high criteria. The achievement of KKM was $83 \%$ classical student achievement and individual more than or equal to 76 .

The average score of student empathy for the environment during practical activities was 82.08. Ali Syahbana (2012) Increasing Junior High School Students 'Critical Thinking Ability Through Contextual Teaching And Learning Approach results that (1) there are significant differences in students' mathematical critical thinking skills between those who use the Contextual Teaching and Learning Approach and use the Conventional Approach, (2) there are significant differences in the improvement of mathematical critical thinking skills between students at the level of early, high, medium and low mathematics knowledge, and (3) there is no interaction between the learning approach and the level of students 'initial mathematical knowledge of students' mathematical critical thinking skills.

Svetlana Stefanova, Jelena Bobkina, France Javier Sánchez-Verdejo Pérez (2017) The Effectiveness of Teaching Critical Thinking Skills through Literature in EFL Context: A Case Study in Spain that examines the use of EFL Context certification to improve students' critical thinking skills. This research resulted in the use of this model effectively, especially in terms of self reflection. In addition, the activity of discussing literary texts and relating them to current problems has proven very useful for students, namely giving them a broader 
perspective that helps them interpret problem in the real world correctly.

In the Indonesian context, we cannot deny that the learning model that is mostly adopted from the west is not suitable to be applied in Indonesia. Not only because the difference of students (literacy, environment, etc.), but also innovative learning models often require a long time. Even though in Indonesia, a curriculum that is at a time and a short time applies. So we need a suitable learning model with the Indonesian context. In this article, researchers have at least two reasons why this study needs to be done, firstly the researchers try to establish alternative solutions for developing critical thinking skills of Indonesian students, namely through the Read- Answer - Discuss - Explain and Create (RADEC) learning model. Secondly, it is important to find solutions that solve problems in the Education world, one of which is a study of how to improve $\mathrm{r}$ critical thinking skills.

RADEC learning model is an alternative learning model that is in accordance with Indonesian conditions (Sopandi, 2017). This model was first introduced by Sopandi (2017) at an international conference in Kuala Lumpur, Malaysia. The name of this model is adjusted to the syntax of Read, Answer, Discussion, Explain, and Create (RADEC). The syntax of RADEC model is easily memorized by primary and secondary education teachers (Sopandi et al. 2018), so it is appropriate to be used for alternative innovative learning models in Indonesia.

Besides easy to memorize the syntax, this model is present on the basis of the Indonesian education system that requires students to understand many concepts of science in a limited time. This model is the latest breakthrough in education that wants the achievement of $21^{\text {st }}$ century competence, character, and literacy accompanied by preparation for examinations held by schools or universities. Some studies have also proven that RADEC learning model has a positive impact on learning outcomes, both material oriented, namely understanding concepts (Lukmannudin, 2018), as well as those that are learning skills oriented namely the ability to think creatively (Jumanto et al. 2018). So it is wise if in this article researchers discuss the RADEC learning model for critical thinking skills. So the title of this article is "Radec (Read-Answer-Discuss-Explain And Create) Learning Model: Building Critical Thinking Skills in the Indonesian Context".

\section{METHODS}

The method used in this article was a literature study. This method consists of identifying, analyzing, and synthesizing relevant research for specific research questions or topics (Kitchenham, 2004) Quoted from Webster \& Watson and Kitchenham, Varvana Myllärniemi identified at least 3 reasons why the literature review was conducted, namely understanding existing topics but fragmented , Understanding new research topics, Studying how theories or methods are supported by empirical evidence (Varvana Myllärniemi, 2015), the sources used in the literature review were in the form of national and international journals, research reports, books, e-books, and other relevant document sources with the some adopted theme.

\section{RESULTS AND DISCUSSION}

Based on the results and discussion, the researcher carefully find research findings and discuss them so that conclusions are generated.

\section{Read-Answer-Discuss-Explain-and Create (RADEC) Learning}

This model is developed on the basis of the following. Firstly, National Education aims to develop the potential of students to become human beings who believe in God, noble, healthy, knowledgeable, capable, creative, independent, and become democratic and responsible citizens. Thus, the practice of education carried out in schools must cover all aspects (attitudes, knowledge and skills). Secondly, education today shows the fact that learning resources in the form of books and other sources such as internet are easily obtained by students. Other facts also show that models from other countries usually do not match with condition in Indonesia. Thirdly, according to Vygotsky's theory of social constructivism, the development of cognitive abilities in children occurs because of interactions with the social environment.

In this theory known the terms such as, actual development level, potential development level and Zone of Proximal Development (ZPD). Actual ability is the ability of students to complete tasks without the help of others. potential ability is the ability of students to complete tasks with the help of others (teachers or peers). While ZPD is the area between actual capabilities and potential capabilities. Based on Vygotsky's theory, learning must be done at that level (Lui, 2012; Vygotsky, 1962). Fourthly, in the first and second grade elementary school students learn to read letters, words, sentences, and paragraphs of text. Next in third grade they learn to improve the understanding of the texts. By often practicing reading students will be more skilled in reading comprehension skills.

The syntax of Read-Answer-Discuss-Explain-and Create (RADEC) learning model is as follows (Sopandi, 2017):

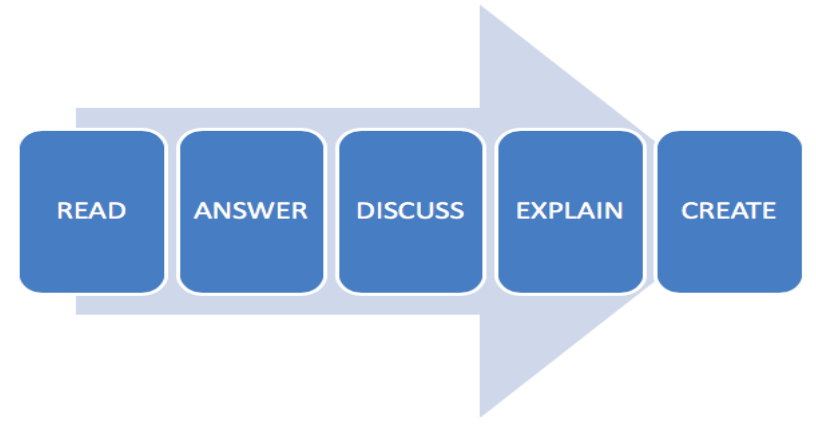




\section{a. Read}

At this stage, students read information from various sources including books, other printed information sources and electronic information sources such as the internet. It is done to guide students in understanding information provided with pre-learning questions. Pre-learning questions are questions related to teaching material. Pre-teaching questions must cover a variety of questions, from low-thinking skills to high-thinking skills. Pre-learning questions are submitted before the teacher carries out the teaching and learning process from teaching materials. Students must answer questions after their reading activities. Their reading activities are carried out independently by students outside the classroom. This is based on the idea that some information can be mastered by student themselves without the others help . Teaching materials that cannot be mastered by students that can ask other students to explain or be explained by their teacher during class sessions. In this way the class session can focus more on the development of other aspects (especially social characters) whose requires interaction with others and if the teaching material found is considered difficult by all students.

At the reading stage of the concept building of critical thinking through reasoning ability is the thing that becomes an emphasis. Critical thinking is a process by using reasoning in making wrong or right decision, and involving logic by distinguishing facts and opinions, fairness, open thinking (Khatib, Mohammad \& Mehrgan, Kamran, 2012). Reading strategy is a key element in developing student understanding (Hülya Küçükoğlu, 2012) besides that, through reading students can improve their skills in terms of reading and understanding the contents of the reading (Gilakjani, Abbas Pourhosein \& Sabouri, Narjes Banou, 2016). By reading, students can construct their knowledge and conclude. The results of research in the US resulted in the 25-year Reading Apprenticeship program being able to help teachers reflect on students' reading independently (Schoenbach, R., \& Greenleaf, C, 2017). The results of other studies resulted in using 40 homogeneous students selected from 93 and resulted that by reading short stories can be a suitable tool to achieve critical thinking skills (Khatib, Mohammad \& Mehrgan, Kamran, 2012).

\section{b. Answer}

At this stage, students answer pre-teaching questions based on the knowledge obtained by the reading activity. Pre-teaching questions are arranged in the form of worksheets. They answer questions outside the classroom or at home independently before the class session is conducted. In this way it is possible for students to identify independently which parts of teaching material are considered easy or difficult. The question of answer is a productive teaching approach in stimulating critical thinking (Rashid, Sumaira \& Qaisar Shahzada, 2016)
Learners can realize themselves whether they are lazy or diligent in reading, it is easy or difficult to understand themselves whether they are lazy or not by written teaching materials, like or dislike reading textbooks, and so on. By using the question level, critical thinking skills can be illustrated by T Santoso et al, 2018, the concept of critical thinking through answering questions is when students try to build arguments using their background by interpreting, analyzing, and responding to problems that require more than one answer (Amin, Astuti Muh \& Adiansyah, Romi, 2018).

Furthermore, by observing the assignments of students and several questions, the teacher can find out about the situation of all students. A person who thinks critically uses choices according in assessing arguments (Indrawatiningsih, Nonik, 2018). It is very likely that the teacher will know that each student needs different assistance. Confirmation or asking becomes the strongest tool of the teacher in examining students' learning and ways of thinking (Arslan, M, 2006). Based on these data, Teacher can provide appropriate assistance for each student. Through the question process to the teacher that can monitor how students' competencies (Musingafi, Maxwell Constantine Chando \& Muranda, Kwaedza Enety, 2014).

\section{c. Discuss}

At this stage students learn in groups to discuss their answers to pre-teaching questions. The teacher motivates students to succeed in carrying out certain tasks from the worksheets to provide guidance to friends who have not mastered them. Teacher motivation becomes an emphasis in the process of traffic discussion. The results of the study using 20 primary schools and 216 respondents produced that there was a significant relationship between motivation and the provision of quality education (Akuoko, Kofi Osei, Dwumah, Peter, Baba Wahab Mahama, 2012).

The teacher motivates students who have not mastered to ask for guidance from their friends. This stage gives students to discuss their answers with other members in one group. At this stage the teacher must ensure that there is communication between participants in each group to get the correct answer. Motivation from the teacher can make students motivated and more successful and be independent (Börü, Neşe, 2018) By looking at the activities of the entire group, the teacher can also find groups that have mastered the teaching material being studied. In this way the teacher can also know the group or those who already have creative ideas as a form of applying the concepts that have been mastered. The sincerity and attitude of the teacher to understand improves the learning process (TALIS, 2009)

\section{d. Explain}

At this stage, presentation is conducted. Teaching materials presented include all learning indicators of cognitive aspects that have been formulated in the lesson plan. The order of presentation is adjusted to the order of 
indicators of learning formulated in the lesson plan. At this stage representatives of these students who have mastered the learning indicators to explain important concepts in front of the class. The teacher ensures that the presenter explains scientifically and correctly and the other students that understand the explanation. Students who apply critical thinking skills are wiser than other and can make more intense questions (Murawski, Linda M, 2014). In this activity, the teacher also encourages other students to ask questions, argue or add to what their friends have said from other groups. The results of the study is in investigating the nine roles of teachers in discussion namely as controller, assessor, regulator, encouragement, participant, informants, facilitator, demonstrator, and as a guide (Miss, Ignatius, 2017).

Besides giving the discussion activities, at this stage it can also be used by the teacher to explain important concepts that it cannot be mastered by all students as observed at the discussion stage. When explaining, the teacher can provide explanations with demonstrations, videos, power points or other things that are expected to overcome the difficulties of the students.

\section{e. Create}

At this stage, the teacher facilitates students to learn and use their knowledge that has been mastered to generate ideas or creative thinking. In the $21^{\text {st }}$ century, creativity is an important element, so teachers need innovation in learning to make students become creative (Gunawan, A Harjono, H Sahidu and Nisrina, 2016). Creative thinking can be formulated as productive questions, problems, or thoughts to make other creative works. Munandar identifies the characteristics of critical thinking, those are flexibility, fluency, originality and elaboration (2002) as mentioned earlier, the task of creating creative ideas or thoughts is included in the pre-learning questions.

At this stage, it only discusses it in the classically because students have previously been assigned to do it independently. When teachers find students having difficulty generating creative ideas, teachers need to inspire students. The source of inspiration given by the teacher can be in the form of examples of research, problem solving or other work that has been done by people. Then students discuss other creative ideas that can be planned and realized. Teacher is the primary informant for students in measuring how much learning can impress students (Pratikno, A. S., Atikoh, N., \& Ningrum, E. F., 2018).

As another inspiration for students, teachers can provide examples of creative plans that have never been realized either by themselves or others. In circumstances students do not have their own ideas so they can work on the teacher's ideas. Realization of ideas can be done independently or in groups depending on the character to be developed. This work is theoretically more challenging for students because of the original idea. The idea of students can emerge from observation, personal interpretation or communicated through the media and talk with others (Chin, Christine, 2001) In addition, ideas can be realized whether successful or unsuccessful. In addition, the realization of ideas can be in class or outside the classroom, can be short or long. This stage trains dominant students to think, work together, communicate.

\section{CONCLUSION}

From the data analysis done by researcher, it can be concluded that one solution to be able to build critical thinking skills in the Indonesian context is to use the RADEC learning model (read-answer-discuss-explain and create). Critical thinking skills are important to be developed because of the demands by time changing. The approach in learning that is done by the teacher plays a role in fostering critical thinking skills. The teacher needs to use a learning model that can stimulate students' critical thinking skills.

\section{REFERENCES}

Alifa Noora Rahma, (2012). Pengembangan Perangkat Pembelajaran Model Inkuiri Berpendekatan Sets Materi Kelarutan Dan Hasilkali Kelarutan Untuk Menumbuhkan Keterampilan Berpikir Kritis Dan Empati Siswa Terhadap Lingkungan. Journal of Educational Research and Evaluation JERE 1 (2) http://journal.unnes.ac.id/sju/index.php/jere

Amin, Astuti Muh\& Adiansyah,Romi,(2018). Lecturers' Perception On Students' Critical Thinking Skills Development And Problems Faced By Students In Developing Their Critical Thinking Skills. JPBI (JURNAL PENDIDIKAN BIOLOGI INDONESIA) Indonesian Journal of Biology Education. Vol. 4 No. 1, 2018; pp. 1-10 ISSN: 2442-3750 (print); ISSN: 2527-6204 (online).

http://ejournal.umm.ac.id/index.php/jpbi

Arslan, M, (2006). The Role Of Questioning In The Classroom. Hasan Ali Yücel Journal of Education, 2, 81-103

Börü, Neșe , (2018). The Factors Affecting Teacher-Motivation. International Journal of Instruction. Vol.11, No.4 e-ISSN: 1308-1470, p-ISSN: 1694-609X,

Chin, Christine. (2001). Eliciting Students' Ideas and Understanding In Science: Diagnostic Assessment Strategies for Teachers. Teaching and Learning, 21(2), 72-85 Published by Institute of Education (Singapore)

F. Fakhriyah, (2014). Penerapan Problem Based Learning Dalam Upaya Mengembangkan Kemampuan Berpikir Kritis Mahasiswa. Jurnal Pendidikan IPA Indonesia. JPII $3 \quad$ (1) (2014) 95-101. http://journal.unnes.ac.id/nju/index.php/jpii

Gunawan, A Harjono, H Sahidu and Nisrina,(2016). Improving students' creativity using cooperative 
learning with virtual media on static fluida concept. International Conference on Science Education (ICoSEd) IOP Publishing. Journal of Physics: Conf. Series doi :10.1088/1742-6596/1006/1/012016

Hafsah Jan, (2017). Teacher of 21st Century: Characteristics and Development. ISSN (Paper) 2224-5766 ISSN (Online) 2225-0484 (Online) Vol.7, No.9, 2017 www.iiste.org

Helen B. Boholano, (2017). Smart Social Networking: 21st Century Teaching And Learning Skills. Research in Pedagogy, Vol. 7, Issue 1 (2017), pp. 21-29 DOI: $10.17810 / 2015.45$

Huilya Küçikoglu, (2012). Improving reading skills through effective reading. kdeniz Language Studies Conference 2012. Procedia - Social and Behavioral $\begin{array}{llllll}\text { Sciences } & 70 & \text { (2013) } & 709 & \text { - } & 714\end{array}$ doi:10.1016/j.sbspro.2013.01.113

Indrawatiningsih, Nonik, (2018). Arguments in Critical Thinking Ability. Advances in Social Science, Education and Humanities Research, volume 218. First International Conference on Science, Mathematics, and Education, (ICoMSE 2017). Atlantis Press

Khatib, Mohammad \& Mehrgan, Kamran, (2012). Advances in Digital Multimedia (ADMM) 166 Vol. 1, No. 3, 2012, ISSN 2166-2916

Munandar, S.C Utami. (2002). Creativity and giftedness Strategy Delivering Creative Potential and Talent.Jakarta: Granada Pustaka Utama.

Musingafi, Maxwell Constantine Chando \& Muranda, Kwaedza Enety, (2014). Students and Questioning: A Review of the Role Played By Students Generated Questions in the Teaching and Learning Process. Studies in Social Sciences and Humanities. Vol. 1, No. 3, 2014, 101-107

Murawski, Linda M, (2014). Critical Thinking in the Classroom....and Beyond. Journal of Learning in Higher Education. Spring Volume 10 Issue 1

Ni Putu Ayu Nopta Apsari, (20160. Teacher's Way To Foster Critical Thinking In The Classroom (A Case Study of a Senior High School in Bandung). Journal of English and Education , 4(1), 51-72

Pratikno, A. S., Atikoh, N., \& Ningrum, E. F. (2018). Teaching method for inspiring the students of the future: A brief review. Researchgate. DOI. 10.13140/RG.2.2.18330.08643

Rashid, Sumaira \& Qaisar Shahzada, (2016). Developing Critical Thinking through Questioning Strategy among Fourth Grade Students. Bulletin of Education and Research. December Vol. 38, No. 2 pp. 153-168

Rindu, Ignatius, (2017). Teacher's Role in Managing the Class during Teaching and Learning. Journal of Linguistic and English Teaching. P-ISSN: 2477-1880; E-ISSN: 2502-6623 Vol. 2 No. 1
Schoenbach, R., \& Greenleaf, C. (2017). Leading for literacy. Phi Delta Kappan, 99(3), 59-64.doi:10.1177/0031721717739596

Sopandi, W., Pratama, Y. A., \& Handayani, H. (2019). Sosialisasi dan Workshop Implementasi Model Pembelajaran RADEC Bagi Guru-Guru Pendidikan dasar dan Menengah, Pedagogia: Jurnal Pendidikan, 8 (1), hlm. 19-34.

Saido, G. M., Siraj, S., Nordin, A. B. B., Al Amedy, O. S. (2015). Higher Order Thinking Skills Among Secondary School Students in Science Learning, The Malaysian Online Journal of Educational Science, Volume 3 Issue 3, hlm. 13-20.

T Santoso et al,(2018) J. Phys.: Conf. Ser. 953012042. doi :10.1088/1742-6596/953/1/012042

TALIS, (2009). Chapter 4: Teaching Practices,Teachers' Beliefs and Attitudes. Creating Effective Teaching and Learning Environments: First Results from TALIS - ISBN 978-92-64-05605-3 87. OECD

Tembang, Y. Sulton, \& Suharjo. (2017). Peningkatan Motivasi Dan Hasil Belajar Melalui Model Pembelajaran Think Pair Share Berbantuan Media Gambar Di Sekolah Dasar. Jurnal Pendidikan Universitas Negeri Malang. 2(6): 812-817.

Sopandi, W. (2017). the Quality Improvement of Learning Processes and Achievements Through the Read-Answer-Discuss-Explain-and Create Learning Model Implementation. Dalam prosiding 8th pedagogy international seminar 2017. Vol 8, 132-139.

Sopandi, W., Pratama, Y. A., \& Handayani, H. (2019). Sosialisasi dan Workshop Implementasi Model Pembelajaran RADEC Bagi Guru-Guru Pendidikan dasar dan Menengah, Pedagogia: Jurnal Pendidikan, 8 (1), hlm. 19-34.

Jumanto, Sopandi, W., Kuncoro, Y., Handayani, H., \& Suryana, N. (2018). The Effect Of Radec Model And Expositorial Model On Creative Thinking Ability In Elementary School Students In Suralaya. Dalam Syaodih, Sujana, Handayani \& William (Penyunting). Prosiding International Conference on Elementary Education (hlm. 561-567). Bandung: Universitas Pendidikan Indonesia.

Kusuma, M. D., Rosidin, U., Abdurrahman, \& Suyatna, A. (2017). The Development of Higher Order Thinking Skill (Hots) Instrument Assessment In Physics Study, IOSR Journal of Research \& Method in Education (IOSR-JRME), 7 (1), hlm. 26-32, DOI: 10.9790/7388-0701052632

Permendikbud, Tentang Kurikulum Tahun 2013

Emily R. Lai, (2011). Critical Thinking: A Literature Review Research Report. London: PEARSON

Kitchenham, Barbara.(2004). Procedures for performing systematic reviews. Technical report TR/SE0401, Keele University 
Maya Bialik, Charles Fadel, (2015). Skills for the 21st Century: What Should Students Learn?. Boston: Center for Curriculum Redesign

Binkley, M., et al. (2012). "Defining Twenty-First Century Skills" dalam Assessment and Teaching of 21st Century Skills. New York: Springer.

Trilling, B. \& Fadel, C. (2009). 21st Century Skills: Learning for Life in Our Times. San Francisco: Jossey-Bass A Wiley Imprint.

OECD. (2013). PISA 2012 Results: What Students Know and Can Do Student Performance in Mathematics, Reading and Science Volume I.

OECD. (2017). Educational Opportunity for All. https://doi.org/10.1787/9789264287457-en

Nugroho, R. A. (2018). HOTS (Kemampuan Berpikir Tingkat Tinggi: Konsep, Pembelajaran, Penilaian, dan Soal-soal). Jakarta: PT Gramedia Widiasarana Indonesia

Lukmanudin. (2018). Penguasaan Konsep IPA dan Kemampuan Menjelasakan Perpindahan Zat Pencemar Mahasiswa PGSD melaui Pembelajaran Read-Answer-Discuss-Explain-and Create. (Tesis). Jurusan Pendidikan Dasar Sekolah Pascasarjana Universitas Pendidikan Indonesia.

Lui, A. (2012). Teaching in the Zone. An Introduction to Working Within the Zone of Proximal Development (ZPD) to Drive Effective Early Childhood Instruction.

Vygotsky, L.S. (1962). Thought and Language: Kap. 6 The Development of Scientific Concepts in Childhood, Übersetzt von Eugenia Hanfmann und Gertrude Vakar, New York and London: MIT Press - John Wiley \& Sons, Inc, S.

Varvana Myllärniemi, (2015). Literature review as a research method. Espoo : Aalto University School of Science. 